magnesia, and potash, and the remaining iron changed to the peroxide state. The length of time required for the water to penetrate a piece of trap I know not; but that the soluble power of the water is great, is evident, by placing a piece of such rock in distilled water ; 100 grains digested for six days, at summer heat, lost one per cent. : the water had an alkaline reaction, and contained magnesia, potash, and lime." Mr. Napier exhibited a specimen of a boulder, showing "the powerful action constantly going on in the earth, changing the character of rocks;" and he also remarks, that "the crust or outer portion of stones of this soil have generally been looked upon as incrustations, from the water in which they have been placed having salts in solution that have become deposited upon the stone or kernel portion. Such incrustation does take place upon organic substances placed in mineral waters; but in this instance, as in most other minerals, the change has evidently been caused by the decomposition of the original stone."

Not far from the town of Lochwinnoch, on the road to Kilbarchan, in which parish it is situated, stands one of the most remarkable erratics in the west of Scotland. Mr. William Fulton, M.A., Govan, first informed me of its existence, and last July both of us measured it. 'The immense basalt fragment, judging from the direction of the deep and broad scratches on its south-east side, appears to have been

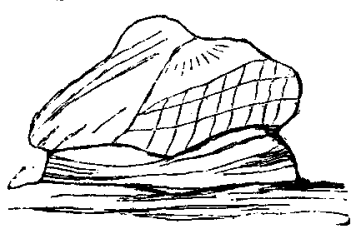

Fig. 8.-Erratic block, Lochwinnoch. carried along in two directions; the force, either ice or running water, thus causing the marks or scratches to cross one another almost at right angles. (See sketch.) The stone is 11 feet in beight and about 69 feet in circumference, and appears to be two miles west of the town of Kilbarchan. The stream called St. Bride's Burn is not very far from the erratic, which receives the local name Clochodrickstone, said to be from the Gaelic, meaning the Druid's stone.

\title{
AN ATTEMPT TO CORRELATE THE GLACIAL AND POST-GLACIAL DEPOSITS OF THE BRITISH ISLES, AND TO DETERMINE THEIR ORDER OF SUCCES- SION.
}

\section{By Professor Winliam Kina,}

Of the Queen's University, Ireland, and the Queen's College, Galway.

The classification given in the sequel is based on the following premises :-

1st. The entire area of the British Isles has undergone at different times, during the Glacial and Post-Glacial periods, a succession of secular elevating and subsiding movements.

2nd. At the close of the Pliocene period, the relative level of land 
and sea over the British area was approximately the same as at present.

3rd. The edge of the two-hundred-fathoms submarine plateau, on the east side of the North Atlantic, formed the west coast-line of a continent (now represented by Europe) during the earliest time (epoch) of the Glacial period.

4th. The climate of the British area was frigid in the extreme during the Glacial period, allowing epochs of amelioration.

5th. Rock-surfaces undergo euormous degradation when they are above the sea-level, during the prevalency of glaciation.

\section{General Observations on the above.}

1st Premiss. Besides the great vertical movements which characterized the Glacial period, there are evidences, hereafter noticed, that it was marked by minor vertical oscillations. Further, it is probable that the former were not of equal magnitude over the entire area of the British Isles; land might be standing somewhat higher or lower in the east than in the west; the same difference may have prevuiled meridionally.

2nd. The "Cromer Norway Spruce-forest" bed evidently formed a land-surface at the close of the Pliocene period; while the overlying "Runton Leda myalis clay" shows that the forest-bed became afterwards submerged. Further, the shells occurring in the Runton deposit may be accepted as a clear proof that the sea in which they lived was Arctic in its temperature; the same may be affirmed of the "Norwich Crag" sea. There is no novelty in these conclusions. Doubtless the elevated regions of the British area, during the prevalency of the Pliocene Arctic temperature, were undergoing glaciation. It is equally admissible that the then German Ocean was traversed by icebergs, transporting blocks from northern latitudes. These considerations lead me to assume that the foreign erratics, common in the unstratified drift or till of the north of England and the more southern counties, are Pliocene in age, and that they afterwards became mixed with lowland accumulations of field- and mountain-glacier débris, formed during the earliest division of the Glacial period, that is, when the bed of the German Ocean was all a terrestrial surface. I doubt that any Pliocene foreign erratics are anywhere to be seen under their original form of accumulation.

3rd. My late investigations on the soundings obtained by H.M S. Porcupine* have convinced me that the remarkable rapid-sinking edge of the two-hundred-fathoms submarine plateau, forming the Irish seabed, as well as the extension of this edge, both north and south, has been cut away by the North Atlantic when its waters were confined within the bounding meridians of the two-miles-deep submarine plain, across which it is proposed to run the telegraph cable from Ireland to Newfoundland. Geological evidences go far to prove that the above

* See my papers in the 'Nautical Magazine' of November and December, 1862 (a corrected copy of which appeared in the 'Daily News' of December 24, 1862); also my "Reply to Dr. Wallich's Statements," Naut. Mag., March, 1863.

VOL, VI. 
oceanic conditions prevailed in the earliest epoch of the Glacial period. Mr. Godwin-Austen has already enunciated a similar opinion.*

The Irish submarine plateau is bounded by sloping sides, which generally sink down to about 10,000 feet, or nearly 1700 fathoms, before reaching the general level of the plain alluded to, with an inclination ranging from 400 to 1000 feet in the mile; the lowest being off Galway (Hoskyn), and the highest on the coast of Kerry, where, howerer, there is also a 548-feet incline. The surface of the plateau appears to be marked by three terraces of different levels. First. The outer edge of this, the lowest terrace, is not naturally defined by the 200-fathoms line, as one of the names of the plateau seemingly implies, but rather by one of 220 fathoms; as it is from the latter line that the most sudden descent is made into deep water. Second. This terrace is limited by the 115-fathoms line, there being here a well-marked break, before reaching shallow water. Third. In passing from the last line to the shore, we meet with a rise about the 35 -fathoms line. It is not well defined; but there appears to be rather an abrupt ascent from 45 to 35 fathoms. When these terraces were subaerial, the first was probably upwards of 1300 feet above the sea, the second nearly 700 feet, and the third upwards of 200 feet.

The vertical movements assumed as having taken place in subsequent epochs of the Glacial and Post-Glacial periods are in a great measure based on the present premiss.

4th. The first epoch of the Glacial period is generally admitted to have been the coldest. It is my belief that the then British area, with all the land now beneath the German Ocean, also that forming the Irish "two-hundred-fathoms plateau," was shrouded with an enormously thick pall of field- and mountain-glaciers. My views on this subject are in no respect less ultra than those advocated by Agassiz and Ramsay. Probably during the earliest portion of the next or subaqueous epoch, the climatic conditions were not much less rigorous: the removal of blocks from low to high levels, in the way suggested by Darwin, requires the coasts to have been thickly girded with ice, like the shores of east Greenland and other Arctic lands at the present day. The close of this epoch appears to have been affected by a somewhat milder climate, which continued into the third (or second subaerial) epoch. If I am right in ascribing, with Agassiz and Lyell, the origin of the Glen Roy terraces to a glacier lake, it may be inferred that the last stage of this epoch enjoyed a still more ameliorated climate; probably ending with a mean temperature more or less resembling that now prevailing in the British Isles.

5th. While I quite agree with Ramsay as regards the powerful degradation which the rock-surfaces of the British area underwent during the Glacial period, I must also contend, from what has already been stated under the first of my premises, that our elevated regions

* Quarterly Journal of the Geological Society, vol. vi. p. 86. I formed the opinion before learning that $\mathrm{Mr}$. Godwir-Austen had advanced a similar one. 
were considerably eroded by glaciers during the close of the Pliocene period.

Before entering on the next subject, it is necessary for me to mention that I wish the greater part of the insertions in the table to be taken in an approximate sense; a few of them, such as "Irish Round Towers," are offered suggestively.

\section{Remarks on the Phenomena of the Glacial and Post-Glacial periods noticed in the Table.}

The two periods under immediate consideration are strongly differentiated both by their physical and organic features. It is unnecessary to add more to what has already been stated on the former. The Glacial period was characterized by the presence of species of the genera Elephas, Rhinoceros, and Hippopotamus, doubtless as amply protected against a severe frigid clinate as the Bear, Walrus, Musk Buffalo, Balene Whale, now inhabiting the ice-bound regions of the Arctic Circle. The Post-Glacial period appears to have been always marked by the absence of the genera above named, at least in the area of the British Isles. The shells special to the glacial period are such as still inhabit the Arctic seas : a few, but very few, may have become extinet. Whether any new species have come into existence during the Post-Glacial period is a question which I am uuable to answer; but it would appear that a few are special to this term, if we confine our observations to the British and adjacent seas,- - the following species, Lima excavata, Haliotis tuberculata, Fusus Berniciensis, and Litorina litoralis, being unrecorded in Glacial and Pliocene deposits. The genus Homo belongs to both the glacial and post-glacial period: it was represented as early as the close of the subaqueous epoch or the beginning of the second subaerial division of the Glacial period by a low form or extinct species, - a view strongly countenanced by the Neanderthal skeleton, as well as the rudely-chipped flint-implements occurring in the elephant gravels of Amiens, Hoxne, and other places. Probably a higher type existed at the same time, as indicated by the skulls found in the Engis caves near Liége. The "Borreby people" of the Post-Glacial period appear to have descended from the Neanderthal race. How far back in geological time it was that the genus made its first appearance on our planet is a question yet to be solved. There is no reason, however, to doubt that it was represented by species during the Pliocene, or even the Miocene period.

The line of demarcation between any two epochs, also between the Glacial and Post-Glacial periods, I assume as being formed by terrestrial and oceanic conditions corresponding to the present relative level of land and sea.

\section{Glacial Period.}

Tirst (subaerial) epoch.-The elevation of the British area, although the land is assumed to have been thirteen hundred feet $(=220$ fathoms) bigher than it is at present, is not, in my opinion, to be regarded as the cause of the severe climatic conditions of this epoch. 
Our present genial temperature, as correctly remarked by Lyell, is exceptional, and it appears to be in some measure due to the Gulf Stream; but, as maintained by Ramsay, some general cause must bave operated in producing the extreme frigid climate of the Glacial period, considering that it prevailed over an immensely wide geographical area, irrespective of the area being successively under continental and oceanic conditions, as it was during the first and second epochs. A pparently, the climate was somewhat less rigorous towards the close of the second epoch, and during the one to which I shall next advert.

Second (subaqueous) epoch.-I have considerable doubt that terrestrial, fluriatile, or littoral animal life existed, except very partially, in the British area under the severe conditions of temperature of the first (subaerial) epoch; and I am disposed to apply a similar doubt to the early division of the one under consideration. This is the reason why I have excluded fossiliferous deposits from the two stages respectively forming the close of the subaerial, and the beginning of the subaqueous epoch.

The shells found by Trimmer on Moel Tryfaen (1400 feet in height), and named by Forbes, do not positively indicate an Arctic climate; but this ray be accounted for on the supposition that the deposit containing them is of littoral origin. Deposits formed, contemporary with the "Moel Tryfaen Shell Drift," at the bottom of a deep sea, would contain shells of a decidedly Arctic character. At the present time, the littoral zone of the west coast of Ireland is tenanted by southern species (Diodonta fragilis, Avicula Tarentina, Circe minima, ete.); while in the comparatively deep water (100 fathoms) of the platean, already noticed, there occur the following subarctic species, Leda pygmaa, Limopsis aurita, Macandrevia cranium, etc. The "Airdrie (Lanarkshire) Tellina calcarea clay" may be regarded as the equivalent in geological time of the "Moel Tryfaen Shell Drift;" but formed in deep water.

The removal of blocks from low to high levels, in some cases several hundred feet, by the action of shore ice on a gradually subsiding coast may be referred to the first half of the epoch, though I am disposed to think that the same phenomenon, but on a smaller scale, was also produced by land ice during the preceding epoch.

The remarkable broad terraces, deeply cut out of limestone beds (Carboniferous), characterizing the waving slopes of the Clare Hills (1000 feet in height) on the south side of Galway Bay, have evidently been formed, as the land rose out of the sea from a depth of not less than 1000 feet: every terrace indicates a stoppage in the uprising.* It is impossible to conceive that these terraces were formed in the subsiding stage of this epoch, or during any portion of the preceding one : there is also considerable difficulty in the way of sup-

* I noticed these tenraces at the Dublin meeting of the British Association, in 1857, in connection with the remarkable jointing associated with them. An abstract of a paper, which contained a further notice of this jointing, is given in the British Association Report of 1857 . Professor Jukes has also noticed the terraces and jointing of the Clare Hills in his 'Manual of Geology,' 2nd edit., 1862. 
posing that they were produced in the Pliocene period, inasmuch as they could not have escaped being planed down and obliterated in the first epoch of the Glacial period. The glaciers of this last period, I am led to believe, have mainly contributed in giving the Clare Hills, before they became terraced, their leading contours. It does not appear that the terraces, considering their well-defined edges, were affected to any extent by the glaciation of the epoch next to be noticed, except perhaps in the valleys (which run down the slopes), where they are only faintly exhibited.*

Some of the freshwater deposits which I have placed in the opening stage of the next epoch may belong to the closing stage of this epoch. The land was evidently undergoing minor oscillations at the time, as shown by Prestwich, in his description of the section at Shacklewell Lane, West Ilackney, which "affords a clear indication of two gravel periods, separated by an interval of dry land."* I see no reason to doubt that the large earth-crust movements, characterizing the "epochs" of the "Glacial period," were ocasionally accompanied by minor oscillations.

The "Brighton ancient sea-beach" could not have existed earlier than the close of this epoch, otherwise it and its protecting cliff would have been swept off by the powerful glaciation of the previous (subaerial) one.

Third (subaerial) epoch.-The Clare Hill terraces have evidently been more acted on by ordinary atmospheric agencies than by glaciation : it is, therefore, difficult to adopt any other conclusion than that the glaciers of this epoch were smaller than those of the former (subaerial) one. Ramsay has formed the same opinion from otber evidences. Still the glaciers of this epoch must have had considerable power to scour the "old marine drift" out of Cwm-llafar, and to deeply erode the rocks of the Brixham, Gower, and Wookey-hole districts. Prestwich has shown that much of the "Biddenban flintimplement gravel" has also been removed by glacial ageney. All these phenomena appear to me to be geologically contemporaneous, and, of course, subsequent to the formation of the gravel last noticed. This deposit, however, does not seem to have been formed by the agency of ice, although the one may have indirectly contributed to the formation of the other. A question next arises-What gave rise to the glaciers which scooped out the "Biddenham flint-implement gravel," and effected the other erosions above alluded to? Were they produced by an elevation of the land? or are they to be attributed to some other cause-the land remaining at its old level? Although unable to adduce any positive evidence in favour of either of the views involved in these questions, I am, nevertheless, inclined to adopt the one which admits that the second glaciation arose, in the districts named, and in the British area generally, in consequence of a great but gradual elevatory movement, which stopped when the second or 115-fathoms terrace of the Irish submarine plateau became elevated above the sea. Considering, however, the diminished

* Journ. Geol. Soc. vol. xi. p. 110. 
TABULAR VIEW OF THE GLACIAL AND

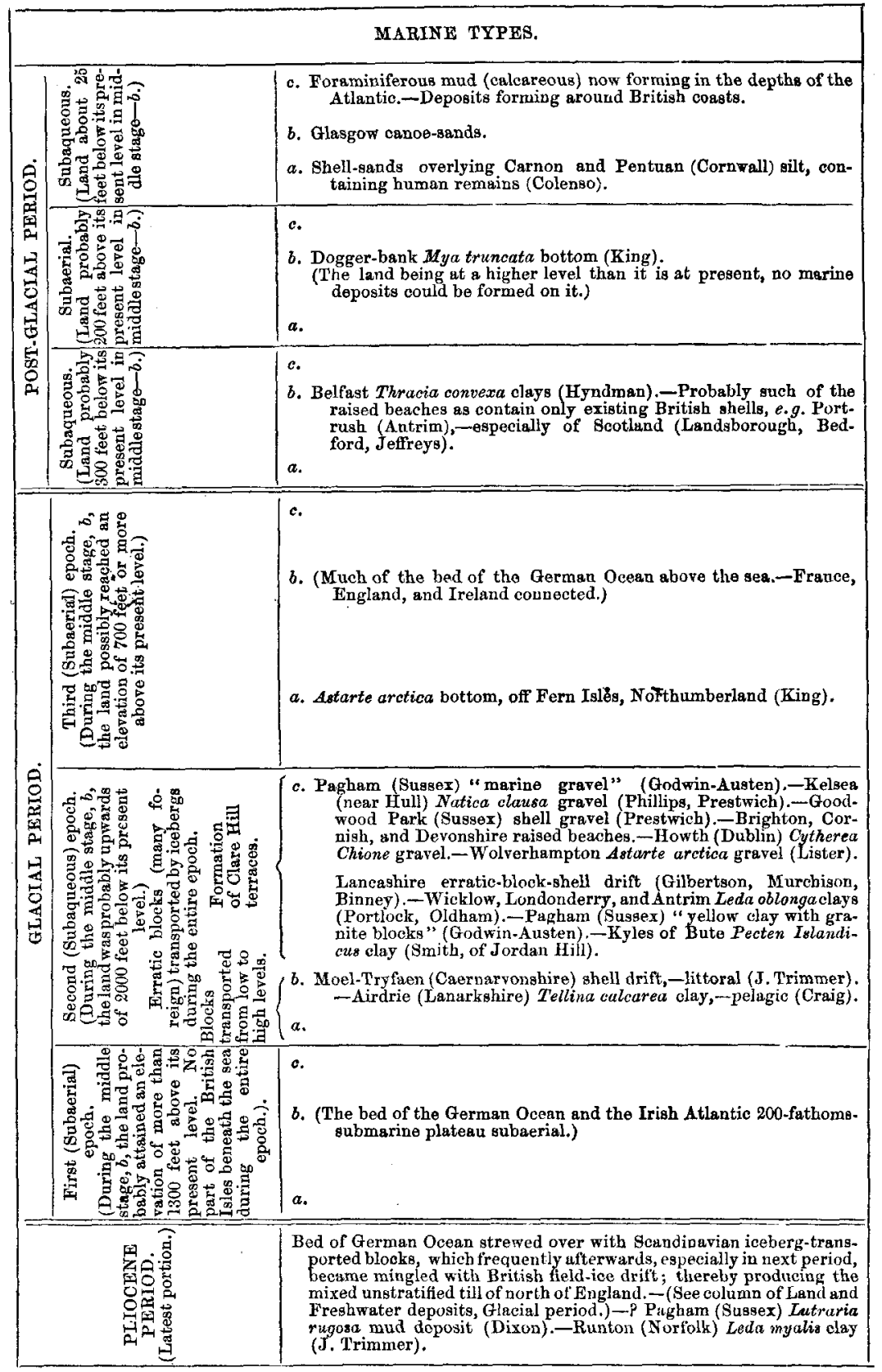




\section{POST-GLACIAL DEPOSITS, CHIEFLY BRITISH.}

\section{IAND AND FRESHWATER TYPES.}

c. Peat, marl, and other deposits, now forming in lakes, rivers, etc.

$b$.

a. ? Irish round towers,-Egyptian pyramids.

c. P Stonehenge.

Carnon and Pentuan (Cornwall) silt, containing human remains (Colenso).

b. Cardigan Scoteh fir submarine forest (Yates).

Irish submarine peat bogs. (? Dogger-bank and much of the German Ocean above the sea. Ire-

land and Spain united: present Asturian flora of S. and W. of Ireland, the remnants of that union.) a. ? In Denmark, "Borreby people" living.

c.

b. Kiltiernan (Co. Dublin) Reindeer deposit (Oldham).

Irish apland forests.

Irish and Isle of Man Megaceros Hibernicus marls (Forbes).

a.

(c. Menchecourt (Valley of the Somme) low-level flint-implement gravel (Estuarine).-Mun desly (Norfolk) Hydrobia marqinata beds (Lyell).-Brentford (Thames) mammaliferous gravel (Morris). - River Air (Yorkshire) Hippopotamus alluvium (Denny).

b. Last glaciation of British Isles, during which Caernarvonshire " marine drift" was scoured out-Cwm-liafar, Nant Francon, etc. (Darwin, Ramsay); old unstratifled till swept off land surfaces and rearranged (Escars); Brixham (Fengelly), Gower (Falconer), and Wookey-hole (Dawkins) rocks, with ossiferous flssures, eroded; also high-level flintimplement gravels of Biddenham, Amiens, and St. Acheul, in part washed off.-Copford (Essex) "brown clay with boulders" (Brown).

a. Copford (Essex) Helix incarnata marl (Brown).--Infilling of Brixham (Devonshire), Gower (Glamorganshire), Wookey-hole (Bomersetshire), and other ossiferous fissures.-St. Acheul and Amiens high-level flint-implement gravels.-Cropthorn (on the Avon) Cyrena consobrina alluvium (Strickland).-Horne (Suffolk) and Biddenham (Bedfordshire) flint-implement gravels. - Grays (Eseex) Unio litioralis bed.

c. Cromer contorted drift (Lyell).

b. (No subnerial surfaces within the area of British Isles, except highest mountains, (Lyell, fig. 39 , p. 276.)

(Subaerial surfaces much decressed; as represented by Lyell, 'Antiquity of Man,' fig. 40, p. 287.)

a. ? Muswell Hill (near London) drift.

c. Much unstratifled till, formed in preceding stages, eroded and rearranged.-Copford (Essex) "grey gravel with boulders" (Brown).

b. Highest and lowest regions enormously glaciated, the resulting debris (unstratified till) often becoming mixed with the Scandinavian iceberg-transported blocks of the Pliocene period, especially in the area of the German Ocean (not in existence at this time). - Much of the surfacefestures of the British Isles formed. Antrim basaltic plateau in many districts deeply eroded; formation of valleys of the Thames, Bevern, Tyne, Tees, ete.

a.

Highest mountain-regions of British Isles under glaciation.

Cromer (Norfolk) Norway spruce-forest bed. 
size of the glaciers of this epoch, it may be inferred that the land did not attain the altitude it had during the preceding (subaerial) one. Possibly the land, as indicated by the depth of the second terrace, never rose more than 700 feet beyond the level it stood at when the "Biddenham flint-implement gravel " was in course of formation, that is, about the present relative level of land and sea. Probably the field-glaciers were wholly, or to a considerable extent, melted in the summer months, thereby giving rise to extensive land-floods. According to this view, the rocks of the then upland plains [enormously abraded in the first (subaerial) epoch] would again be ground down by glacial action in winter ;* while in summer, the torrents of water arising from melted ice would sift the glacier débris, piling its blocks, pebbles, and sand into banks (Escars) and mounds, and sweeping the mud into adjacent lakes and seas. This last glaciation would remove or destroy many of the marine deposits formed in the "subaqueous epoch:" hence their scarcity. The Lancasbire and Warwickshire shell-deposits have escaped its destructive power.

I quite agree with Prestwich in referring the flint-implement gravels of the Seine and the Somme to two distinct epochs, between which great physico-geographical changes took place.t The oldest (or highest) of these gravels appears to have its counterpart in that occurring near Biddenham. I am not able to correlate any British flint-implement gravels with the youngest (or lowest) occurring at Menchecourt and other French localities ; but it is highly probable that some of those recently discovered by Prestwich, Evans, Whitaker, and others are the equivalents in geological time of those forming the lowest series at the mouth of the Somme.

* The flat country lying between Dublin and Galway would, under the conditions named in the text, form an upland plain. From all $I$ can observe, the district around Galway has been covered with subaerial drift (formed during the first glacial epoch) of not less than 300 feet in thickness; I fud patches of it lying at a height equal to the number of feet mentioned at Tonabrocken. Much of this drift, in my opinion, has been considerably worn down completely or swept away, at the close of the first and in the midale of the second subaerial epochs. On the worn-down undulating surfaces of this old drift, erratic blocks of granitic rocks, etc., are common : these, I corsider, have been transported by, and dropped from, iccbergs during the subaqueous epoch of the glacial period. Much information on the subject of Irish drifts and erratics is given by Din Noyer in his highly interesting paper, published in the 'Geologist' of last July. Notwithstanding its original great thickness, the singular fact is common around Galway, that in no case where the limestone has been denuded of the subaerial drift do the wide cracks and joints prevalent in the rock contain a particle of it : one would have imagined the very contrary. I can ouly account for its absence on the view, advanced in the text, that the limestone, on which the drift was originally deposited, has, in addition to the degradation which it underwent towards the close of the first (subaerial) epoch, been much abraded by the winter glaciation of the third (subaerial) one; " thereby exposiug beds which were not uppermost when the drift was in course of deposition.

+ Apparently Mr. Prestwich does not go so far in the views stated as I do. All the evideuces bearing on the physico-geographical changes noticed in the text show that the intervening time, between the epochs to which the two series of flint-implement gravels are referred, was of enormons length. The Rev. Mr. Symonds correctly observes that the physical geology of the oldest or highest of the Somme valley gravels "proves their immense antiquity even more than do their fossil remains." (Geology of the Railway, p. 14.) 
The formation of the gravel terraces of Glen Roy appears to have taken place in the last half of this epoch-when the land was subsiding. Had they existed previously, they must have been obliterated by glaciation. Nothing affords a better explanation of their origin than the view originally advanced by Agassiz, and lately adopted by Lyell, that they were formed in a valley converted into a lake by the damming up of its mouth with a glacier which descended from Ben Neris. Admitting that the Glen Roy terraces have been formed in this way, it must be conceded that the land was at the time gradually yet intermittently subsiding. While the subsidence was going on, it may be safely assumed that the glacier-dam became more and more reduced in height, causing at the same time the level of the lake. water to fall lower and lower, until, finally, both glacier and lake disappeared altogether. Possibly the melting of the glacier was facilitated by the gradual setting in of the more genial climatic conditions which prevailed in the succeeding epoch. It is unnecessary to suppose that the land, when subsiding, descended beneath its present level in the last stages of the lake and glacier.

The way in which the glacier-lake of the Märjelen-see is formed and sustained, that is, by the glacier of Aletsch, as described by Ramsay, may be accepted as a good illustration, on a small scale, of the origin of the old glacier-lake of Glen Roy.

\section{Post-Glacial Period.}

First epoch (subaqueous).-There are several mountain bogs in the west of Ireland containing the remains of rooted trees which could not, under present conditions of temperature, grow at their present elevation. I am strongly inclined to believe that they grew at a lower level. The "Belfast Thracia convexa clay" may have been deposited about the same time in deepish water.

Second epoch (subaerial).-During this epoch, considerable portions of the submarine area between the south of Ireland and the coast of Spain, and averaging about 200 feet in depth, was elevated above the level of the sea, giving rise to a land-surface which botanically connected these two countries. The connection, althougb now physically severed, is still maintained, as Forbes noticed in 1846, by the presence of Asturian plants-Dabeocia polifolia, Pinguicula grandiflora, Arabis ciliata, Trichomanes radicans, etc.-in Kerry and Connemara. Forbes conceived that the "destruction of the intermediate land took place before the Glacial period;"* but since he wrote, the researches of Ramsay, Prestwich, Lyell, Trimmer, Godwin-Austen, Jamieson, Falconer, Pengelly, Chambers, and numerous others, in PostPliocene geology, render it highly probable that the "destruction" occurred at a much later period; in short, that Ireland, England, and Spain were united during the earliest age of tin-mining in Cornwall.

In numerous places on the Irish coast there occur extensive sub. marine peat-bogs, which, it is evident, cannot have been formed when the forests last noticed were growing as supposed, or at the present

* Mem. Geol. Survey, vol. i. p. 348 .

VOL. VI. 
relative level of land and sea. They must have been formed when the land was higher than it is at present,-perhaps not more than 200 feet. These submarine peat-bogs may have been formed contemporaneously with the shell-deposit next noticed.

Some years ago, when dredging on the west side of the Dogger Bank, off the coast of Durham, in about 50 fathoms water, the dredge brought up a large quantity of dead specimens, in a chalky condition, of Mya truncata (Annals Nat. Hist. vol. xviii. p. 233). It is impossible to conceive that these specimens of a iittoral species lived at the deptb from which they were procured; wor can 1 admit that they have been transported from a shallower habitat by marine currents. There is less difficulty in contending that they lived on the spot which yielded them, when the Dogger Bank was a subaerial surface; and that the species ceased to live in the locality when the land became submerged.

Third epoch.-Influenced by the investigations of Geikie, also by some considerations given in a notice which I have elsewhere published ('Parthenon,' No. 50, April 11, p. 417), I am led to believe that the "Glasgow canoe-sands" are not so ancient as some archæologists have conceived. Possibly some portion of this deposit may be of high prehistoric antiquity ; but evidently some of it was formed when Scotland was occupied by the Romans.

Admitting the view just stated to be correct, it necessarily follows that the geological epoch under consideration includes the historical era of our country. A question now suggests itself-A re the slight vertical movements of the Post-Glacial period equal in chronological value to the much larger ones of the Glacial period? Or anotherAre they simply equivalents of the minor oscillations which accompanied the great movements of the latter term? Considering the magnitude of the physico-geographical changes which characterized the Glacial period, as compared with those of the following one, I feel most inclined to adopt the view comprehended in the last question. In this case it may be contended that the Post-Glacial period has not yet advanced beyond its initial stages.

\section{SPECULATIONS ON POSSIBLE PHYSICAL AND COS- MICAL PHENOMENA IN REFERENCE TO THE PAST CONDITIONS OF OUR EARTH.}

By S. J. MACKIE, F.G.S.

Whenever we begin to think about the formation of the universe we get at once into the realms of speculation, and the only value of our thoughts rests in their probability. In everything unknown we must first form an idea-that is, speculate ; then, by partial gatherings of facts, or by positive reasoning, we may theorize. Ultimately, by the accumulation of evidence, we may prove that which, in the 